\title{
DO SOCIAL CRISES CAUSE RELIGIOUS REVIVALS? WHAT BRITISH CHURCH
} ADHERENCE RATES SHOW

\author{
Abstract \\ A 2014 sociology of religion conference invitation asserted that it is 'A long-standing \\ assumption in the sociology of religion ... that there is a correlation between religious \\ resurgence and intense moments of political, economic and socio-cultural crisis'. We test this \\ proposition against various post-1900 British or UK church adherence data and find no \\ evidence to support the claim. On the contrary, the trajectories of decline are remarkably \\ smooth. We suggest that such smoothness better supports the sociological view of \\ secularization as a long-run process with amorphous and deep causes than it supports the \\ claim that religious change is a response to specific events.
}

Keywords: crisis, crises, religious revival, religious resurgence, secularization

\section{Introduction: Is Decline Smooth or Episodic?}

The rubric for the 2014 annual conference of the British Sociological Association's Sociology of Religion Study Group said:

A long-standing assumption in the sociology of religion is that there is a correlation between religious resurgence and intense moments of political, economic and sociocultural crisis. We are living at such a moment of crisis now.

We are somewhat sceptical of the assertion in the first line. Those sociologists of religion working in the Max Weber-Bryan Wilson secularization tradition explain the decline in the power, popularity and plausibility of religion by reference to long-standing and deep-rooted abstract social changes such as the rise of individualism and egalitarianism, the growth of religious diversity, the growth of a this-worldly pragmatism encouraged by increasingly effective technology, the growing neutrality of the state, and the like (for a summary see Bruce 2012). The religiosity of distinct populations may for a period take on a character specifically connected to their circumstances. Migration, for example, often produces a shortlived increase in attention to the migrants' shared religion and groups opposed to migrants may try to deploy supposed threats to the host religion in their anti-immigrant rhetoric. But the assertion of the first sentence seems far too broad to be accurate for those sociologists who work within the secularization paradigm. 
Equally well, those sociologists (normally described as supply-side, religious market, or rational choice theorists) who most forcefully oppose the secularization model are hardly likely to suppose a correlation between religious resurgence and 'intense moments of ... crisis' because they assume the demand for religion to be pretty well stable (for a summary, see Young 1997). What explains the visible differences in levels of religiosity is the supply of religion and the various constraints on that supply: that is, market structure. Possibly Pippa Norris and Ronald Inglehart's explanation of worldwide variations in levels of religious commitment could be shoe-horned into the above rubric if it was flipped over. They argue that 'transcendent religion is usually weakened by a sense of existential security - that is, the feeling that survival is secure enough that it can be taken for granted' (Norris and Inglehart 2010: 3). They are primarily concerned with human development over long periods of time, however, and do not themselves speculate about the impact of short-term reversals.

Arguably there is some anthropological precedent. Bronislaw Malinowski's Trobriand Islanders performed magic rituals before fishing in the unpredictably dangerous open sea but not before fishing in enclosed shallow and thus safer bodies of water (Malinowski 1961). And the religion-as-response-to-danger trope is common in popular accounts of the evangelical faith of British fishing and mining communities (for a mining example, see Rule 2002; for a fishing example see Clark 1982 or Griffin 1992). However, an attempt to compare the religious commitments of various groups of County Durham miners found that the Methodism that was supposedly a response to the dangers of mining was more popular among lead miners (whose work was arduous but not unpredictably dangerous) than among either shallow or deep pit colliers (Bruce 2011).

Even if serious scholars did not make it, a connection between religious resurgence and crisis is common. Believers often assert that 'There are no atheists in fox-holes'. This is a reference to the shallow depressions in which soldiers try to hide from gunfire and bombardment rather than to fox-hunting and it is attributed by Wikipedia to a 1939-45 war correspondent but it represents the perennial proposition that extremis prompts the search for divine assistance (for an account of religion among British soldiers in the 1914-18 war, see Cairns 1919). A communal form of the proposition is also common: that if we face some major calamity such as an asteroid strike or nuclear war, people will return to the churches. British news outlets are certainly fond of assuming a link between crisis and religiosity. For example, the banking collapse in 2008 was reported with stories of markedly increased attendance at services in City of London churches. However, such reports are so patently formulaic that they probably tell us more about the clichés of news reporting than about 
British church attendance: indeed the text of a Daily Telegraph story headlined 'Church attendance rises as recession deepens' shows that the clergy interviewed were patently reluctant to endorse the reporter's suggestion that 'the national mood is changing ... we are turning our backs upon the hollow materialism of recent years and lifting our hearts to a higher, more spiritual plane' (Farndale 2008: 1).

This paper tries to test the proposition that social crises provoke religious revival with various measures of religious interest in Britain or the UK. We first consider difficulties of identifying crises and operationalizing and measuring religious resurgence. We then present a variety of data on British or UK church involvement and consider to what extent such data support the claimed association. These allow us to introduce the larger and somewhat neglected point that, once begun, the decline in church adherence is, for a naturally-occurring phenomenon, fairly regular. This has important implications beyond the specific issue of religious responses to social crises. Many historians (for example, Nash 2004) see changes in the popularity of religion as having local and immediate causes. Sociologists working within the secularization paradigm believe the causes of secularization to work by altering the social environment in ways that are often obscure to those eventually affected by them. For example, the gradual weakening of state endorsement of Christianity (which affected school and higher education, religious broadcasting, and the overall status of the faith at different rates) is likely to have a gradual rather than episodic effect on the plausibility of religious belief systems. And if it is the case that increasing religious pluralism weakens the intergenerational transmission of religious commitments by increasing positive interaction between people of different faiths and thus increasing the proportion of mixed denomination marriages (which in turn weakens the associations that the children of such marriages can make between having a particular religion and being virtuous), such an effect will work gradually through generations. The supposed multi-faceted nature of secularization makes it inherently difficult to test but the importance (or otherwise) of periodic social crises does give us something to consider. If the decline of church adherence over the twentieth century and our recent austerity years is reasonably smooth then the long-run sociological perspective looks more plausible than any account based on responses to dramatic social events.

A final introductory note about remit. Most of our data relates to Britain: that is, to England, Wales and Scotland. The United Kingdom also includes Northern Ireland (NI) and NI figures form a very small part of the data presented in Figures 2, 3 and 5 but we have not separately examined any NI series because the political history of the province adds too many additional 'crises' to distinguish any period as 'normal'. We could have used international 
survey data to examine a range of western European countries but given that different countries experienced what might be regarded as crises at different times. it seems more sensible to consider one country alone and to leave it to experts in other countries to repeat the test for themselves. In basing our argument on British or UK data we are not supposing that Britain or the UK is some sort of bellwether but equally well we do not suppose it to be entirely idiosyncratic. It would be interesting to perform similar tests on societies with Lutheran national churches or on hegemonically Catholic countries but a single country test offers a neat and clear place to begin. And to return to the starting point of this introduction, the assertions about the influence of social crises which stimulated this paper were both universal and locally specific. Of course the patterns we find in one country - especially one with an usually complex religious culture - cannot crucially test the general argument but they are a useful place to start.

\section{Operational Considerations}

This may seem obvious but, as the point is sometimes missed, we will state the obvious. The difficulties we are about to consider are as much problems for those making the crisis/resurgence claim as they are for those of us who are sceptical. They hinder those who wish to support the claim as much as they hobble those who doubt it and rejecting our evidence is not in itself warrant for any other assertion.

The problems in testing both ends of the causal connection presented in the opening quotation can be grouped in two realms. First there are those associated with agreeing on what would count as 'a moment of crisis' bad enough to fuel religious resurgence. Second come those associated with agreeing on what would count as evidence of a religious resurgence.

The difficulties with the notion of crisis are 'how bad?' and 'for whom?'. Circumstances which in hindsight seem barely troublesome are often described as crises: sociologists will be familiar with Jurgen Habermas's Legitimation Crisis (1976) and Alvin Gouldner's The Coming Crisis in Western Sociology (1970). In 2014 the European Journal of Social Theory published a special issue on 'Europe in Crisis' (volume 17; number 3) in which the authors identified a very wide range of 'crises' concerning economic efficiency, legitimation, the democratic deficit, the future of transnational society, migration, labour rights and much more. The frequent recourse to the term suggests few limits to what can be so denoted. 
And 'for whom' is equally troublesome. Economic depressions are often discussed as if they were a problem for everyone when even severe depressions may leave large part of the population unaffected. The memoir of a young Scots Christian woman whose husband was posted to his company's head office in London in the mid-thirties waxes lyrical about the wonders of the Metropolis, the church services they attended and the friendships they made without mentioning the general economic climate despite accidentally blundering into the subject when she describes the dismal view of Glasgow slum tenements from the train south (Traill Lyon 1993: 1). Those lucky enough to remain in secure well-paid work may actually enjoy a rise in living standards in a depression as the wage rates of those whose services they employ are forced down. Even wars have beneficiaries. During the Second World War, British farmers were mostly exempted from conscription, enjoyed a plentiful diet, and saw the prices for their produce rise.

The problem with religious resurgence is operationalizing and measuring it. The obvious measure in a Christian country is church involvement. Contra to those who assert that one does not need to attend church to be a good Christian, every Christian church, sect and denomination encourages its adherents to gather regularly for mutual encouragement and education and for the collective worship of God. The Catholic Church goes so far as to make the absence from worship without good reason a sin. So the obvious expectation is that a religious resurgence will show itself in increased numbers of people attending church. Given that attendance data are rarely complete for long periods and for more than a few churches, membership may be a reasonable surrogate. After all, were there a major upsurge in attendance, we would expect a lot of that to translate into increased membership. In both of those example we are supposing that 'resurgence' means more people being or becoming religious. A weaker claim is that the proportion of the religiously observant remains the same but that they become more so: regular churchgoers are fired up by a crisis and so attend more often. But that is beginning to seem a rather tepid religious resurgence. We can certainly think of examples of a religious response by religious people to horrific events. The day after the London Tube bombings, many Anglican churches left their doors open so that people could light candles and say prayers for the dead. But that they knew where the church was and how to light candles and say prayers in side-chapels suggests that those who took part in such acts of remembrance were already churchgoers.

\section{Twentieth Century Crises}


Notwithstanding all of the above, if we are to assert that crises cause religious revivals, we ought at least to seek some evidence and it seems reasonable to suppose that, whatever others one may want to add to the lists, during the twentieth century the UK faced three crises the Great War of 1914-1918, the Depression of 1928 to c. 1936, and the 1939-45 war - of sufficient severity that one can imagine that very large parts of the population were touched by them and hence that any religious reaction should have been large enough to show up in data on church involvement. We now present a variety of church membership data that span those crises.

\section{English Methodism}

We begin with some data on Methodist membership. Methodism is particularly valuable to the statistician because, as well as representing the largest body of English Christians outside the state church and Roman Catholicism, its officials were punctilious in recording and reporting membership data. As the many extant chapel, circuit and district records show, chapel stewards reported membership four times a year. Furthermore, as the overall picture was not visible until the figures had been totalled at district level, it was impossible for stewards to 'fix' their returns to suit a particular outcome. Anyway, for very many circuits it is possible to compare the quarterly returns with the society membership books, and although a few lazy stewards rolled totals over from one quarter to another, the arrival of a new superintendent minister every three years always occasioned a thorough purging of nominal members.

Table 1 Methodism in England around here

The pattern of Methodist decline in England is remarkably even. So that the rate and direction of change can be seen clearly, the final column shows the percentage change on the previous decade (that is, acceleration rather than velocity): the falls from one decade to the next vary by less than half a percent and for four decades the variation is one quarter of a per cent or less. How do our three crisis decades compare to the others? Two of them - those encompassing the First World War and the Depression and the start of the Second World War - show the largest declines. None of them shows growth relative to the adult population. Hence we can conclude that English Methodism offers no support for the religious resurgence claims. 


\section{Shetland Methodism}

Shetland Methodism is described in Figure 1. Arguably data from one denomination in one small part of the UK should be ignored because it may well display the effects of unusual local social changes (such as migration) but we include it because it shows very clearly something that is a feature of changes in religious adherence in other countries. In net terms Shetland Methodists fell from a peak of 1,627 in 1903 to a low of 1,292 in 1920 before growing again to peak at 1,395 in 1925. There are very slight and brief upswings in 1940 and again in the late 1940s. The former might possibly be described as a revival stimulated by the onset of war but the First World War and the Depression left no obvious trace and the trajectory since the late 1920 s can best be described as a steady decline.

To illustrate the evenness of decline we have added to the graph a line for a simulation based on the conjecture that from the turn of the century every three Shetland Methodists in one generation were replaced by only two in the next. Specifically, we assume that a) all age groups are equally religious at the outset; b) people in each new cohort entering adulthood are two thirds as likely as their parents (who are 29 years older) to be members; c) there is no conversion in or out after age 21 ; d) everyone lives to be 70 . As can be seen, this model is very similar to the observed decline. Voas and Crockett (2005) suggest that in Great Britain overall, religious involvement currently has a half-life of one generation: that is to say, on average people are only half as likely to identify, practice or believe as their parents. The Methodist decline in Shetland during the period 1900-1986 is not quite as rapid, but it shows all the signs of being the result of long term social change, relatively unmarked by short term disturbances.

Figure 1 around here

\section{Scots Presbyterianism ${ }^{l}$}

Because ministers were chosen by a vote of all adults on the membership roll, the Church of Scotland has comprehensive membership figures. Although not revised as frequently as Methodist figures, they were always updated when there was a ministerial vacancy. Table 2 shows the membership of the Church of Scotland and the various schismatic alternatives (such as the United Free Church). Is there any evidence of a religious resurgence in our three crisis decades? That which encompasses the First World War shows decline of 0.82 per cent,

\footnotetext{
${ }^{1}$ We would like to thank Callum Brown of the University of Glasgow for supplying these data.
} 
much the same as the decade before it. The decade which includes the Depression and the start of the Second World War shows a large decline. Only the third of our crisis decades shows growth and that is both slight and less than that of the succeeding decade. So Scottish Presbyterianism does not seem to support the case that crisis provokes religious resurgence.

Table 2 Scottish Presbyterian etc around here

\section{Sunday School Attendance}

Were large numbers of people who were previously unconnected to the churches now turning to religion, we might expect them to send their children to Sunday school. Table 3, which shows changes in the proportion of school age children attending Sunday schools in England and Wales, offers no support for the resurgence claim. It may well be that the 1931 figure is a mistake and the actual pattern of change is of accelerating decline over the twentieth century. But in any case there is no sign that the putative crisis decades saw any growth or even slowing of the rate of decline. ${ }^{2}$

Table 3 Sunday school enrolments around here

\section{UK Church Membership}

In case it be thought that we are selecting data which best make our point, we now present data for total church membership in the UK. ${ }^{3}$ Figure 2 shows net membership; Figure 3 shows the same data presented as a proportion of the total population.

Figures 2 and 3 around here

As one can see both the rise and fall in total number is relatively smooth. When presented as a percentage of the population (as in Figure 3), we can see first that there has been no growth and second that the decline has been relatively smooth. There are plateaus in 1920-5, 1930-5, and 1950-55. It is hard to describe these temporary halts on an otherwise smooth decline 'revivals' but for the sake of argument we can ask how they fit with the crisis argument. The

\footnotetext{
${ }^{2}$ For further data on Sunday school enrolments and an explanation of the historical background, see Field (2014b: 35-37).

${ }^{3}$ We are grateful to Peter Brierley, formerly of Christian Research, for supplying these data and figures.
} 
first comes a little late but allowing a year or two for changes in the real world to work their way through the data-collecting process, we might just see this as evidence of a reaction to the First World War but it may simply represent migration from Ireland. ${ }^{4}$ The second might be a reaction to the Depression. The third does not fit the crisis story and is almost certainly a mark of Irish migration.

\section{Church of England Attendance and Membership}

To avoid the distorting effect of Irish migration, we can look at the Church of England - the largest component of the above UK figures - on its own. As a state church which liked to see all people in the parish as its business, the Church of England did not have a category of 'member' until 1919 when the electoral roll was established but the minimum expectation of an Anglican in good standing is taking communion at Easter. Although many clergy did not complete the attendance columns in the parish registers for normal Sundays, the Easter Day communicant figure was always recorded and it was reported to the diocese for management purposes.

Figure 4 Church of England Easter Day Communicants around here

As can be seen from Figure 4, there are dips and rises in the Easter Day communicant figures but none of the rises occur in places that suggest they were responses to our three twentieth century crises. Indeed, the points for the period in and immediately after the Second World War fall below the trendline.

\section{Twentieth Century Summary}

The above can be summarised while avoiding repetition by considering what social historians take to have been the effects on religion of our three crises. In the most detailed study thus far of the effect of World War I on church attendance and membership, Clive Field notes that 'the onset of war boosted attendance in all denominations for a few weeks' but as the war dragged on Protestant (but not Catholic) attendance fell away (2014: 266). Field concludes 'There is no sign that churchgoing recovered in the post-war years, in either absolute or relative terms' (2014a: 267). Changes in church membership were more complex but the big

\footnotetext{
${ }^{4}$ We have not presented a series of data for British Catholicism because it is near-impossible to distinguish local growth or decline from the effects of population flows to and from Ireland.
} 
picture was 'the continued erosion of adherents ... with accelerated decline for all Churches over the whole inter-war period (2014: 267). Callum Brown writes that 'The Great War presents the social historian with some contradiction' (2006: 111). Traditional church historians see World War I as triggering a loss of faith; 'Other historians have located the war's impact in the context of long-term secularisation' (2014:112). No-one is suggesting subsequent growth. Brown sees little or no effect from either the Depression or the Second World War.

\section{Twenty-First Century Austerity}

The conference rubric we quoted at the start emphatically asserted that in 2014 we were 'living at such a moment of crisis'. The banking collapse of 2008, the subsequent recession and the government's austerity measures certainly created an economic crisis. As we noted some journalists produced the stock religious revival stories but what does the evidence show? Figure 5 shows church attendance from 1990 onwards; ethnic minority respondents are omitted from the sample in order to focus attention on changes brought about by events rather than shifts in the composition of the population. Once again what is striking is the evenness of decline; the financial crisis does not appear to have produced any deviation from the well established linear trend.

Figure 5 Attendance around here

\section{Data Summary}

The many compromises involved in using church membership and similar data are wellknown. However, unless we are going to make unsupported assertions, we have to seek some data that will allow us to arbitrate competing claims. There is no doubting the relative position of start and finish points in these series. Every measure of religiosity was markedly lower at the end than at the start of the twentieth century. What matters for assessing the effects of the twentieth century crises is the patterns of rise and fall between the start and finish. We have presented a number of series of data and while they are sometimes a little lumpy, it is hard to see evidence that the three twentieth century crises - the two world wars and the depression of the 1930s - have produced any visible increase in religious interest. We have looked closely at church attendance data covering the post-2008 banking crisis and 
again noted that the figures offer no support for the claim that the current recession has caused an increase.

\section{Discussion}

The first conclusion from our data - an observation of relevance to all studies of crises - is that there is no obvious association between social crises and religious interest in the UK. That is, the conference rubric with which we began is simply wrong. The explanation for lack of crisis-related surges in religiosity seems obvious. Objective circumstances generally require interpretation before they cause behavioural responses. Thoroughly religious people see world events through the prism of their shared beliefs. Being religious is very largely a matter of early socialization and subsequent reinforcement through regular interaction with like-minded religious people. People who are not religious are unlikely to acquire the interpretative framework necessary to see some event as proof of the truth of that interpretive framework just because they are confronted with an unpleasant state of affairs: there are very many other reactions possible. Where one might expect some crisis-related change in religious commitment is with people who are marginally religious but familiarity with the biographies of such people shows that for every Great War soldier whose faith was reinforced by the horrors of war there was another whose response was to lose faith in a creator God who allowed such things to happen. As examples one might consider the divergent responses of two decorated Great War soldiers: George Fielden MacLeod and Robert Graves. McLeod decided to enter the ministry and later founded the Iona Community (Ferguson 2001). Robert Graves lost his inherited Anglicanism and gave his well-informed response to the "no atheists in fox holes' assertion when he wrote: 'Hardly one soldier in a hundred was inspired by religious feeling of even the crudest kind. It would have been difficult to remain religious in the trenches ...' (1981: 168-9).

While preventing an error becoming part of the scholarly record is useful, our second point in this article is more far-reaching. Like most very big ideas in the social sciences, the secularization thesis is untestable. We can demonstrate that the decline of interest in religion in the West coincides with increasing diversity and egalitarianism, increasing individualism and consumerism, the increasing religious neutrality of the state and the consequent loss of various forms of indoctrination and reinforcement, the churches' loss of social functions and the consequent reduction of the public's contact with organized religion, technology's solution of problems for which religious offices were once the only recourse, an increasing sense that we have mastery over our fate, and so on. But demonstrating causation is another 
matter, especially when the proximate cause of decline is not usually adult defection but the failure of each generation to successfully socialise in the faith sufficient of its children to replace those members who have 'gone on to glory'. That generational failure of transmission is itself often partial rather than complete: committed parents being followed by children who have some familial or heritage loyalty to the church but whose faith is not strong enough to insist that their children acquire even their weak faith. And such gradual detaching often takes the form of 'marrying out', which is both a symptom of a weakening of the faith and a cause of further weakening as, even if the parents agree to raise their children in one particular church, sect or denomination, the fact that one parent is outside that tradition makes it impossible to maintain the implicit claim that only those within the favoured tradition are especially virtuous.

In a nutshell, the sociological view of secularization is that it is a slow process of weakening commitment, the causes of which are many, most largely obscure to the actors involved, which occurs over a number of generations. The contrast is the view favoured by some historians (especially church historians) that the causes of decline are to be found in specific events. This is where our argument with the idea that social crises cause religious revivals gains significance beyond the parochial argument with our colleagues in the British Sociological Association's Study Group of Religion.

It would be a mistake to draw too thick a line between historians as fact grubbers and sociologists as grand generalisers. There are many scholars who would be hard to place on either side: Charles Tilly and Eric Hobsbawm in English or Ferdinand Braudel in French. As the eminent church historian Diarmaid MacCulloch put it: 'Historians aren't people who just list events. Any fool can do that and create a timeline. Historians are people who combine chronology ... with interpretation. We are always interpreting' (2014: 10). Nonetheless, in the case of contemporary studies of religion in the UK, there is something of such a division. Historians Hugh McLeod, Callum Brown, Jeffrey Cox and David Nash have all dismissed the sociological secularization thesis as overly generalizing (McLeod 2007; Brown 2000; Cox 2010; Nash 2004). Nash, in particular, has argued that we need more detailed studies of the events that shaped religion in this or that place (2004). What we have shown is that many trajectories of decline are sufficiently smooth that while detailed local short time span historical studies are doubtless interesting and informative they are not necessary for understanding secularization.

\section{Conclusion}


While our starting point - an argument with a conference rubric - may be parochial our conclusion is anything but. It should be of interest to all students of religious change who write about social crises that, for the UK over the twentieth century, there is little or no evidence that two world wars and a deep economic depression produced a religious response. The decline in British Christianity over the twentieth century is relatively smooth and shows little or no response to what are arguably the three great events of that century. This proves nothing but it does add some weight to the sociological view that secularization is a gradual process rather than a consequence of responses to a series of major events.

\section{Funding}

Some of author A's research alluded to here was conducted while on a Leverhulme Senior Research Fellowship. Author B's research is supported by the ESRC Research Centre XXX. 


\section{REFERENCES}

Bowes, H. (1988) Revival and Survival: Methodism in Shetland. Aberdeen University: MTh thesis.

Brierley, P. (2011) UK Church Statistics 2005-15. Tonbridge, Kent: ADBC Publishers.

Brown, CG. (2006) Religion and Society in Twentieth-Century Britain. London: Pearson Educational.

Bruce, S. (2011) Methodism and miners in County Durham 1881-1991, Northern History, XLVIII, 337-355.

Bruce, S. (2012) Secularization. Oxford: Oxford University Press.

Cairns, DS. (1919) The Army and Religion: An Enquiry and its Bearing upon the Religious Life of the Nation. London: Macmillan and Co.

Clark, D. (1982) Between Pulpit And Pew: Folk Religion In A North Yorkshire Fishing Village. Cambridge: Cambridge University Press.

Cox, J. (2010) Towards eliminating the concept of secularisation: a progress report. In Brown CG and Snape M (eds) Secularisation in the Christian World: Essays in Honour of Hugh McLeod, 13-26. Aldershot: Ashgate.

Currie, R., Gilbert, A, and Horsley, L. (1977) Churches and Churchgoers: Patterns of Church Growth in the British Isles since 1700. Oxford: Clarendon Press.

Farndale, N. (2008). Church attendance rises as recession deepens. Daily Telegraph 6 December. http//www.telegraph.co.uk/topics/chritmas/3630732/Church-attendance-rises-as recession-deepens.html. Accessed 6 March 2014.

Ferguson, R. (2001) George MacLeod. Founder of the Iona Community. Glasgow: Wild Goose Publications. 
Field, C. (2014a) Keeping the spiritual home fires burning: religious belonging in Britain during the First World War, War and Society 33: 244-68.

Field, C. (2014b) Britain's Last Religious Revival? Quantifying Belonging, Behaving and believing in the Long 1950s. London: Palgrave Macmillan.

Gouldner, A. (1970) The Coming Crisis of Western Sociology. New York: Basic Books.

Graves, R. (1981) Goodbye to all That. London: Folio Society.

Griffin, S. (1992) A Forgotten Revival: Recollections of the Great Revivals of East Anglia and North East Scotland of 1921. Epsom: Day One.

Habermas, J. (1976) Legitimation Crisis. London: Heinemann.

Traill Lyon, JM. (1993) The Painted Hat: reminiscences of a minister's wife. Cellardyke, Fife: The author.

MacCulloch, D. (2014) Diarmaid MacCulloch. British Academy Review 23: 10-15.

McLeod, H. (2007) The Religious Crisis of the 1960s. Oxford: Oxford University Press.

Malinowski, B. (1961) Argonauts of the Western Pacific. New York: EP Dutton.

Nash, D. (2004) Reconnecting religion with social and cultural history: secularization's failure as a master narrative. Cultural and Social History 1: 320-325.

Norris, P. and Inglehart, I. (2010) 'Are high levels of existential security conducive to secularization? A response to our critics.' Midwest Political Science Association annual meeting, Chicago, April 22, 2010. 
Rule, J. (2002) 'A risky business: death, injury and religion in Cornish mining c. 1780-1870', Pp. 155-73 in E. W. Herbert, A. B. Knapp and V. C. Pigott (eds), Social Approaches to an Industrial Past: The Archaeology and Anthropology of Mining. London: Routledge.

Voas, D. and Crockett, A. (2005) Religion in Britain: Neither believing nor belonging. Sociology 39(1): 11-28.

Young, L. (1997) Rational Choice Theory and Religion: Summary and Assessment. New York: Routledge. 